\title{
IDENTIFIKASI Bacillus Sp. PADA BEBERAPA TAHAPAN PENGOLAHAN FROZEN TASTELESS SMOKED TUNA
}

\author{
(Identification of Bacillus sp. on Some Points of Frozen Tasteless Smoked Tuna Process)
}

\author{
Hens Onibala ${ }^{1}$ \\ ${ }^{1}$ Fakultas Perikanan dan Ilmu Kelautan, Universitas Sam Ratulangi, Manado Sulawesi Utara.
}

\begin{abstract}
Penelitian ini bertujuan untuk mengidentifikasi keberadaan Bacillus sp. pada produk frozen tasteless smoked tuna dan menganalisa karakteristik Bacillus sp dengan uji mikrobiologi yang berhubungan dengan spesies-spesies yang potensial sebagai pembusuk dan patogen. Sampel yạg digunakan berupa ikan tuna yang diambil dari PT. Sari Tuna Makmur Bitung pada tahapan proses pengolahan yaitu bahan baku, daging tuna yang telah diberi Karbon monoksida (CO) dan produkakhir Pengambilan sampel dilakukan sebanyak 3 kali. Pengujian mikrobiologi meliputi pewarnaan Gram, pewarnaan spora, motility, fermentasi karbohidrat, katalase, indol, methyl red, vogues proskauer, sitrat, oksidase, $\mathrm{H}_{2} \mathrm{~S}$ dan gelatin. Uji karakteristik pertumbuhan yaitu suhu, $\mathrm{pH}$ dan $\mathrm{NaCl}$. Uji karakteristik patogenitas yaitu aglutinasi dan hemolisis. Hasil analisa total Bacillus pada beberapa tahapan proses pengolahan frozen tasteless smoked tuna yang tertinggi ditemukan pada daging tuna yang diberi $\mathrm{CO}$ yaitu $1,1 \times 10^{5} \mathrm{cfu} / \mathrm{gr}$, yang diikuti oleh bahan baku $2,5 \times 10^{4} \mathrm{cfu} / \mathrm{gr}$ dan terendah pada produk akhir 1,9 x $10^{4} \mathrm{cfu} / \mathrm{gr}$. Berdasarkan hasil uji biokimia telah teridentifikasi 2 spesies yang diduga Bacillus yaitu $B$. cereus yang bersifat patogen bagi manusia dan $B$. coagulans yang potensial sebágai pembusuk.
\end{abstract}

Kata kunci: Bacillus, Tuna, Karbon monoksida (CO).

This study aimed to identify the occurrence of Bacillus sp. on the products of frozen tasteless smoked tuna and to analyze the microbiological characteristios of Bacillus sp. including its pathogenic characteristics. Samples were tuna taken from PT. Sari Tung Makmur Bitung, on processing phases, raw material, tuna meat treated with Carbon monoxide (CO) and final product. All Samples were taken on three times. Microbiological analyses, such as Gram-staining, spore staining, motility, fermentation of carbohydrates, catalase, indol, methyl red, Vogues Proskauer, citrate, oxidase, $\mathrm{H}_{2} \mathrm{~S}$ and gelatin were done. The growth characteristics of isolated Bacillus yere also done on some ranges of temperature, $\mathrm{pH}$ and $\mathrm{NaCl}$, while the pathogenic analysis was done with agglutination and hemolysis test. Total analysis of Bacillus on all samples of frozen tasteless smoked tuna showed that the highest in tuna meat treated with $\mathrm{CO}$, approximately $1.1 \times 10^{5} \mathrm{cfu} / \mathrm{gr}$, followed by raw material, $2.5 \times 10^{4} \mathrm{cfu} / \mathrm{gr}$, and then final product, $1,9 \times 10^{4} \mathrm{cfu} / \mathrm{gr}$, respectively According to biochemical test, two 2 species of Bacillus were identified, B. cereus which is potensial as human pathogen and B. coagulans as spoilage bacteria.

Keywords: Bacillus, Tuna, Carborn monoxide (CO).

\section{PENDAHULUAN}

Frozen tasteless smoked tuna merupakan salah satu bentuk produk dari olahan ikan tuna segar yang diberjoetrakuan suhu rendah serta penambahan gas CØ. Pada tahapan proses pengolahannya mulai dari penerimaan bahan baku sampai pada produk akhir masih memungkinkan adanya kontaminasi mikroba khususnya mikroba patogen) Kontaminasi yang terjadi selama tahapan proses pengolahan di pabrik berlangsung dapat diakibatkan karena lingkungan pengolahan yang tidak saniter dan higienis baik peralatan dan air yang digunakan maupun pekerja itu sendiri (Ross et al., 2009; Junianto, 2003; Salasa, 2002).

Bacillus merupakan salah satu jenis mikroba patogen yang dapat menyebabkan penyakit dan intoksikasi pada manusia dan juga menyebabkan kerusakan produk. Bakteri ini terdapat di se- gala tempat yaitu di air, tanah dan udara dan dapat mengkontaminasi produk perikanan seperti ikan tuna. Mengingat akibat yang ditimbulkan maka keberadaan bakteri ini pada produk perlu dihindari (Anonimous, 2009a; Darmayasa, 2008; Jawetz et al., 1982; Wewengkang, 2006; Downes and Ho, 2001; Ijong, 2003; Ijong, 2004; Todar, 2008).

Penelitian ini bertujuan untuk mengidentifikasi keberadaan Bacillus sp. pada frozen tasteless smoked tuna yang berhubungan dengan beberapa tahapan perlakuan penanganan dan pengolahan. Serta menganalisa karakteristik Bacillus sp. dengan uji mikrobiologi yang berhubungan pada jumlah bakteri yang potensial sebagai pembusuk dan patogen. 


\section{METODE PENELITIAN}

\section{Tempat dan Waktu Penelitian}

Penelitian ini dilaksanakan di Laboratorium Mikrobiologi Hasil Perikanan Fakultas Perikanan dan Ilmu Kelautan Universitas Sam Ratulangi Manado. Waktu penelitian selama 3 bulan.

\section{Bahan dan Alat Penelitian}

Bahan baku yang digunakan ialah daging ikan tuna (Thunnus albacores). Media dan reagen yang digunakan yaitu Bacillus Selective Agar, $\mathrm{Nu}-$ trient Broth (NB), Nutrient Agar (NA), $\mathrm{NaOH}$, $\mathrm{NaCl}$, minyak imersi, larutan kristal ungu, alkohol $70 \%$, larutan safranin, larutan lugol, malasit hijau, Phenol Red Broth Base kaldu karbohidrat (glukosa, fruktosa, laktosa, sukrosa dan manitol), Simmon's Citrate Agar, Motility Test Medium, Reagen MR-VP, Reagen Oksidase, Reagen Kovacs dan $\mathrm{H}_{2} \mathrm{O}_{2}$. Sedangkan alat yang akan digunakan adalah cool box, autoklaf, inkubator, cawan petri, oven, mortal, pipet, timbangan analitik, gelas ukur, Erlenmeyer, tabung reaksi, tabung Durham, magnetic stirrer, mikroskop, kaca objek, $\mathrm{pH}$ meter, kuvet, jarum Ose, spatula dan lampu spritus.

\section{Prosedur Penelitian}

Sampel yang digunakan diambil di PT: Sari Tuna Makmur Bitung dengan tahapan proses pengolahan dari penerimaan bahan baku, daging yang telah diberi gas $\mathrm{CO}$, dan daging yangtelah dibekukan serta divakum (frozen tasteless smoked tuna) yang siap ekspor. Sampel tersebut diambil secara acak dengan berat kira-kira $250-500 \mathrm{~g}$, kemudian dimasukkan ke dalam Gastík steril lalu disimpan dalam wadah (coolboy) yang telah diberi hancuran es dengan perbandingan 1:3. Pengambilan sampel dilakukan sebanyak tiga kali.

Analisa total bakteri menggunakan media Nutrien Agar dan analisa total Bacillus menggunakan media Baciltus Selective Agar dengan metode tuang. Sébanyak $25 \mathrm{gr}$ sampel ditimbang secara aseptîs menggunakan Erlenmeyer steril kemudian sampel dihancurkan dan dimasukkan ke dalam $225 \mathrm{NaCl} 0,9 \%$. Buat pengenceran $10^{-1}-10^{-4}$. Masing-masing pengenceran dituang ke dalam cawan petri yang berisi media NA dan Bacillus Selective Agar. Inkubasi selama pada suhu $37^{\circ} \mathrm{C}$ selama 24 jam. Koloni yang tumbuh pada media selektif dipindahkan ke NA miring sebagai kultur sediaan. Selanjutnya dilakukan pengujian secara mikrobiologis yang meliputi pewarnaan Gram, pewarnaan spora, motility, fermentasi karbohidrat, katalase, indol, methyl red, vogues proskauer, sitrat, oksidase, $\mathrm{H}_{2} \mathrm{~S}$ dan gelatin. Berdasarkan ha- sil pengujian maka dilakukan identifikasi berdasarkan Bergey's Manual of Determenative Bacteriology. Setelah teridentifikasi, diambil spesies bakteri yang mewakili spesies yang teridentifikasi untuk digunakan pada uji karakteristik pertumbuhan yang meliputi suhu, $\mathrm{pH}$ dan $\mathrm{NaCl}$. Selanjutnya dilakukan uji karakteristik patogenitas berupa aglutinasi dan hemolisis (Feliatra dan Suryadi, 2004; Yanti, 2005; Roosdiana, 2007).

Hasil pengujian laboratorium yang diperoleh terdiri dari 2 kategori yaitu hasil pengujian kuantitatif dan kualitatif. Hasil kuantitátif diperoleh dengan menggunakan nilai rata-rata Kemudian disajikan dalam bentuk tabel. Sedangkan hasil kualitatif disajikan dalam bentukgambar.

\section{HASIL DAN PEMBAHASAN}

\section{Keberadaan Bacillus Sp. pada Frozen Tasteless Smoked Tuna}

Hasil analisa total bakteri terhadap sampel daging tuna yang diambil pada beberapa tahapan proses pengolahan diperoleh hasil yang bervariasi.

Tabel 1. Hasil analisa total bakteri.

\begin{tabular}{|c|c|c|c|c|}
\hline & \multicolumn{3}{|c|}{ Pengambilan (cfu/gr) } & \multirow{2}{*}{$\begin{array}{c}\text { Rata- } \\
\text { rata }\end{array}$} \\
\hline Sampel & I & II & III & \\
\hline Bahan baku & $2,8 \times 10^{4}$ & $2,1 \times 10^{4}$ & $2,6 \times 10^{4}$ & $2,5 \times 10^{4}$ \\
\hline $\begin{array}{l}\text { Daging yang } \\
\text { diberi CO }\end{array}$ & $1,5 \times 10^{5}$ & $2,5 \times 10^{4}$ & $1,4 \times 10^{5}$ & $1,1 \times 10^{5}$ \\
\hline Produk akhir & $2,1 \times 10^{4}$ & $2,3 \times 10^{4}$ & $1,4 \times 10^{4}$ & $1,9 \times 10^{4}$ \\
\hline
\end{tabular}

Pada sampel bahan baku diperoleh nilai rata-rata $2,5 \times 10^{4} \mathrm{cfu} / \mathrm{gr}$ dan mengalami peningkatan pada daging tuna yang telah diberi gas $\mathrm{CO}$ dengan nilai rata-rata $1,1 \times 10^{5} \mathrm{cfu} / \mathrm{gr}$ kemudian mengalami penurunan kembali pada produk akhir yaitu $1,9 \times 10^{4} \mathrm{cfu} / \mathrm{gr}$. Hal ini disebabkan daging tuna telah mengalami proses pembekuan dan pengemasan vakum. Menurut Ilyas (1983), turunnya suhu sampai $5^{\circ} \mathrm{C}$ menyebabkan bakteri golongan mesofilik tidak berkembang biak lagi. Pada suhu $-1^{\circ} \mathrm{C}$, laju perkembangbiakan bakteri penyebab utama pembusukan ikan dapat ditekan. Selanjutnya Buckle et al., (1987) menyatakan bahwa pengemasan dapat melindungi makanan dari kontaminasi mikroba.

Berdasarkan persyaratan mutu yang dikeluarkan oleh Badan Standarisasi Nasional Indonesia, jumlah bakteri maksimum untuk tuna beku yaitu $5 \times 10^{5} \mathrm{cfu} / \mathrm{gr}$. Sedangkan hasil perhitungan total bakteri pada produk akhir dari sampel daging tuna yang diambil yaitu $1,9 \times 10^{4} \mathrm{cfu} / \mathrm{gr}$. Hasil ini menunjukkan bahwa produk ini layak dikonsumsi mentah (Sashimi).

Seperti pada analisa total bakteri, total Bacillus dari sampel daging tuna yang diambil pa- 
da beberapa tahapan proses pengolahan frozen tasteless smoked tuna menunjukkan hasil yang bervariasi.

Tabel 2. Hasil analisa total Bacillus.

Table 2. Results analysis of total Bacteria.

\begin{tabular}{cccccc}
\hline \multirow{2}{*}{ No. } & \multirow{2}{*}{$\begin{array}{c}\text { Jenis } \\
\text { Sampel }\end{array}$} & \multicolumn{2}{c}{ Pengambilan (cfu/gr) } & Rata- \\
\cline { 3 - 5 } & I & II & III & rata \\
\hline 1. & Bahan baku & $2,4 \times 10^{3}$ & $2,1 \times 10^{3}$ & $2,4 \times 10^{3}$ & $2,3 \times 10^{3}$ \\
2. & Daging CO & $3,9 \times 10^{3}$ & $2,8 \times 10^{3}$ & $4,1 \times 10^{3}$ & $3,6 \times 10^{3}$ \\
3. & Produk akhir & $2,1 \times 10^{3}$ & $2,4 \times 10^{3}$ & $1,3 \times 10^{3}$ & $1,9 \times 10^{3}$ \\
\hline
\end{tabular}

Total Bacillus tertinggi terdapat pada daging tuna yang diberi $\mathrm{CO}$ yaitu $3,6 \times 10^{3} \mathrm{cfu} / \mathrm{gr}$ yang diikuti oleh bahan baku $2,3 \times 10^{3} \mathrm{cfu} / \mathrm{gr}$ dan terendah pada produk akhir $1,9 \times 10^{3} \mathrm{cfu} / \mathrm{gr}$.

Sama seperti pada total bakteri, pada sampel daging tuna yang diberi $\mathrm{CO}$ jumlah Bacillus yang ditemukan juga mengalami peningkatan. Hasil ini mempertegas bahwa pemberian gas $\mathrm{CO}$ tidak menghambat pertumbuhan Bacillus. Pemberian gas $\mathrm{CO}$ merupakan salah satu upaya menurunkan kandungan oksigen $\left(\mathrm{O}_{2}\right)$. Gas $\mathrm{CO}$ akan berikatan dengan sisa $\mathrm{O}_{2}$ yang ada dalam plastik, sehingga gas $\mathrm{CO}$ akan berubah menjadi gas $\mathrm{CO}_{2}$ yang dapat menghambat pertumbuhan bakteri pembusuk yang umumnya bersifat aerobik. Sebaliknya bakteri kontaminan khususnya bakteri yang bersifat anaerob fakultatif seperti Bacillus masih dapat bertahan pada kondisi tanpa oksigen (Feliatra dan Suryadi, 2004). Menurut Buckle et al, (1987), naiknya kandungan $\mathrm{CO}_{2}$ menghalangi perkembangan bakteri Gram-negatif yang pertumbuhannya cepat dan membiarkan Gram-positif yang pertumbuhannya lambat dan tahan terhadap $\mathrm{CO}_{2}$. Selanjutnya Ross et al, (2004) metaporkan bahwa pemberian gas $\mathrm{CO}$ tidak dapat menghambat pertumbuhan mikroba namun hanya mempertahankan warna merah daging tuna dan mencegah terjadinya perubahan oksimioglobin menjadi metmioglobin atau dikena dengan reaksi pencoklatan/ mailard. Gas CO bereaksi dengan oksimioglobin membentuk suatu senyawa kompleks yang stabil yaitu karbeksimioglobin yang memberikan warna merąh pada daging tuna (Anonimous, 2009b).

Jumlah Bacillus pada produk akhir mengalami penurunan. Ini berarti metode pembekuan dapat menekan pertumbuhan Bacillus. Namun keberadaan Bacillus pada produk akhir menunjukkan bahwa bakteri ini masih dapat bertahan pada suhu beku walaupun tidak dapat berkembang biak lagi. Menurut Buckle et al, (1987), kebanyakan mikroorganisme tahan terhadap suhu rendah sampai suhu pembekuan walaupun pertumbuhan terhambat namun sel-sel bakteri dapat tahan hidup untuk jangka waktu cukup lama.
Berdasarkan hasil yang diperoleh, jumlah Bacillus pada produk akhir yaitu $1,9 \times 10^{3} \mathrm{cfu} / \mathrm{gr}$. Ini menunjukkan bahwa produk ini masih dapat dikonsumsi. Kandungan B. cereus dalam bahan pangan yang menyebabkan keracunan berkisar $3 \times 10^{5}-2 \times 10^{9} \mathrm{cfu} / \mathrm{gr}$ (Supardi dan Sukamto, 1999).

\section{KESIMPULAN}

Hasil analisa total bakteri dan Becillus pada beberapa tahapan proses pengolahan frozen tasteless smoked tuna menunjukkanjumlah tertinggi pada tahapan daging yang diberi $\mathrm{CO}$ kemudian diikuti bahan baku dan terendah pada produk akhir. Dengan demikian produk tersebut masih dapat dikonsumsi karena masih đibawah standar jumlah bakteri yang menyebabkan keracunan pada manusia.

\section{DAFTARPUSTAKA}

Anonimous. 2009al Foodborne Pathogen. www.stopreadymeals:xon(phdi/p1.nsf. [20 Maret 2009]

2009b. Carbon Monoxide Treated Tuna. wwy. ava.gov.sg/CarbonMonoxideTreatedTuna1.pdf. [28 Februtari 2009].

Buckle, K.A., R.A. Edwards., G.H. Fleet dan M. Wooton. 1987. Ilmu Pangan. Penerjemah : H. Purnomo dan Adiono. UI-Press. Jakarta.

Darmayasa, I.B.G. 2008. Isolasi dan Identifikasi Bakteri Pendegradasi Lipid (lemak) Pada Beberapa Tempat Pembuangan Limbah dan Estuari DAM Denpasar. Jurnal Bumi Lestari. Vol. 8 No. 2. Hal. 122-127 Universitas Udayana Denpasar.

Downes, F.P. dan K. Ho. 2001. Compendium of Methods For The Microbiological Examination of Foods. American Public Health Association.

Feliatra, I.E. dan E. Suryadi. 2004. Isolasi dan Identifikasi Bakteri Probiotik dari Ikan Kerapu Macan (Ephinephelus fuscogatus) dalam Upaya Efisiensi Pakan Ikan. Jurnal Natur Indonesia. Vol. 6 No. 2 Hal. 75-80. ISSN 14109379. Universitas Riau Pekanbaru.

Ilyas, S. 1983. Teknologi Refrigerasi Hasil Perikanan. Jilid I. Teknik Pendinginan Ikan. CV. Paripurna. Jakarta.

Ijong, F.G. 2003. Penuntun Praktikum Mikrobiologi Pangan Ikani. Fakultas Perikanan dan Ilmu Kelautan Universitas Sam Ratulangi. Manado.

2004. Bahan Ajar Mikrobiologi. Fakultas

Perikanan dan Ilmu Kelautan Universitas Sam Ratulangi. Manado.

Jawetz, E.J.L., J.L. Melnick dan E.A. Edelberg. 1982. Mikrobiologi Untuk Profesi Kesehatan. Editor Gerard Bonang. Edisi 14. Penerbit Buku Kedokteran. Jakarta.

Junianto. 2003. Teknik Penanganan Ikan. Penebar Swadaya. Jakarta.

Ross, M.P., R.M. Benner, C.D. Benton, and W.S. Otwell. 2009. The Influence of Exposure to Carbon Monoxide on The Quality Attributes for Yellowfin Tuna Muscle. sst.ifas.ufl.edu/25thAnn/file12.pdf. [28 Februari 2009]. 
Roosdiana, A. 2007. Isolasi dan Karakterisasi Bacillus sp. Penghasil Protease Dari Kulit Ikan Kakap Merah (Luganuss sanguineus). library.trunojoyo.ac.id/elib/ detil.php?id. [18 Juli 2009].

Salasa, F.F.A. 2002. Teknologi Pengolahan Ikan dan Rumput Laut. Pusdiklat Perikanan. Departemen Kelautan dan Perikanan. Jakarta.

Supardi, I. dan Sukamto. 1999. Mikrobiologi Dalam Pengolahan dan Keamanan Pangan. Penerbit Alumni. Bandung.
Todar, Kenneth. 2008. Bacillus cereus Food Poisoning. www.textbookofbacteriology.net/B.cereus.html. [26 Mei 2009]

Wewengkang, L.A.J. 2006. Keracunan Makanan Oleh Bakteri. Prosiding Pertemuan Ilmiah Tahunan Perhimpunan Mikrobiologi Indonesia.

Yanti, D.I.W. 2005. Karakteristik Bacillus sp. Yang Diisolasi Dari Rajungan (Portunus pelagicus) Segar dan Produk Kaleng di PT. Windika Utama Semarang, Jawa Tengah. Skripsi. FPIK Unsrat Manado.

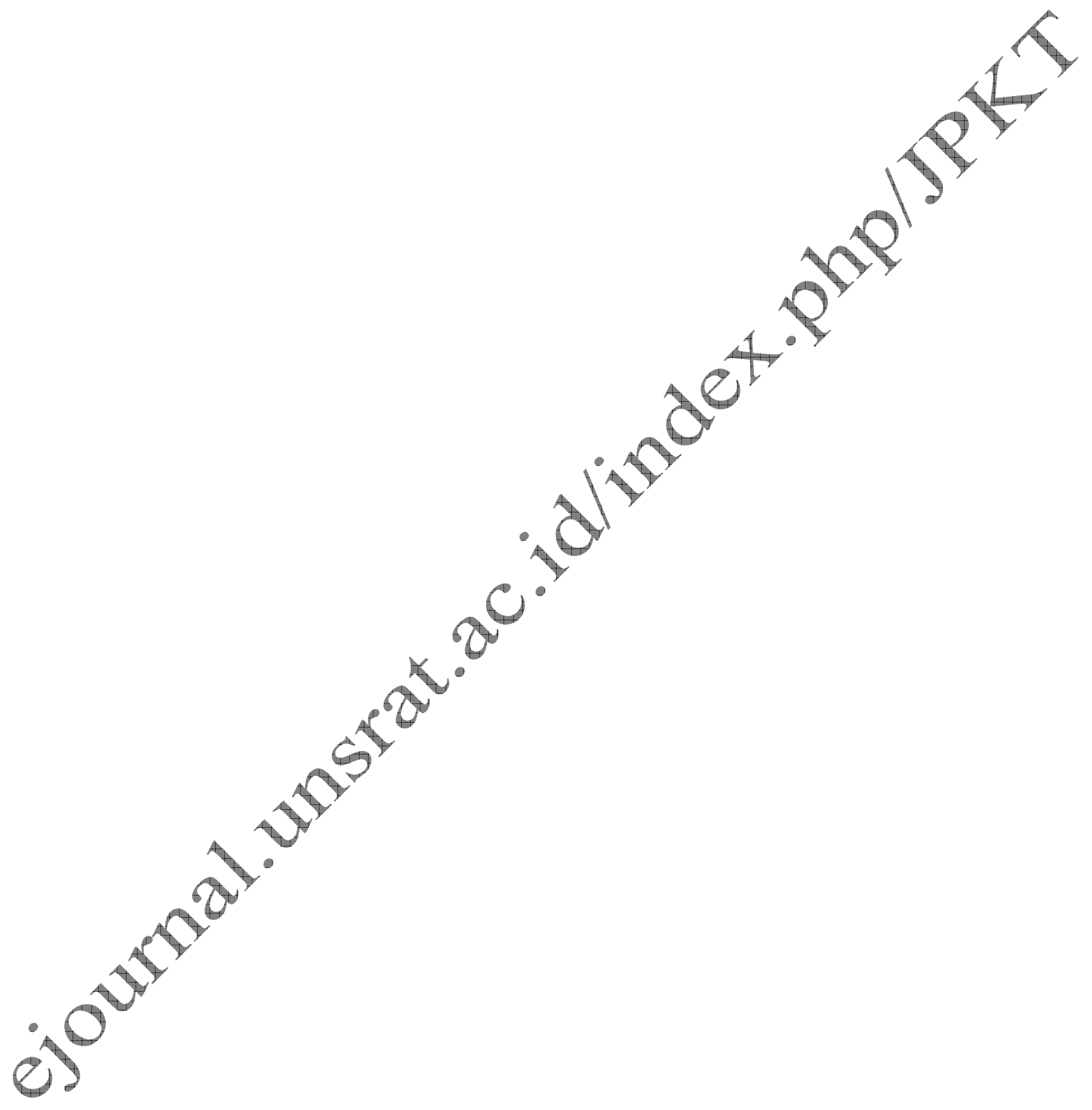

